\title{
Postdigital Ecopedagogies: Genealogies, Contradictions, and Possible Futures
}

\author{
Petar Jandrić ${ }^{1,2}$ (D) Derek R. Ford ${ }^{3}$ (D)
}

Accepted: 23 November 2020/Published online: 19 December 2020

(C) Springer Nature Switzerland AG 2020

\begin{abstract}
This paper charts some genealogies, challenges, and directions for experimenting with the utopic postdigital ecopedagogies demanded by our present (post)pandemic reality. These are messianic - rather than prophetic — utopias that exist not as proclamations or programmes for a distant future but as potentialities immanent in the irreducible excess of the present. While their roots most clearly emanate from the Freirean-inspired ecopedagogy movement, we conceptualize ecopedagogies instead as educational forms that emerge from, negotiate, debate, produce, resist, and/or overcome the shifting and expansive postdigital ecosystems from and to which we write and think. These are expansive ecosystems of humans, postdigital machines, nonhuman animals, minerals, objects, and more; ecosystems that are overdetermined by new forms of ontological hierarchies and capitalism, imperialism, and settler-colonialism. By charting some of the potential lineages, directions, contradictions, and challenges - and by proposing potential lines of educational praxis - we lay a basis for reinvigorated fields of inquiry that moves beyond the existing postdigital literature on the current pandemic.
\end{abstract}

Keywords Postdigital · Critical pedagogy · Ecopedagogy · Utopia · Environment · Feminism $\cdot$ Queer theory $\cdot$ Data $\cdot$ Algorithms $\cdot$ Intersectionality $\cdot$ Bioinformational capitalism · Virology · Aesthetics · Imperialism - Critical disability studies · Belief - Science and technology studies

Petar Jandrić

pjandric@tvz.hr

Derek R. Ford

derekford@depauw.edu

1 Zagreb University of Applied Sciences, Zagreb, Croatia

2 University of Wolverhampton, Wolverhampton, UK

3 DePauw University, Indiana, USA 


\section{We Need New Utopias}

As we write these words in November 2020, the Covid-19 pandemic approaches its first anniversary. Reflecting on our early responses to the pandemic, ${ }^{1}$ we cannot but notice significant changes in our thinking and feeling over the past months. During our first lockdowns in Spring, the pandemic seemed like a terrible event that we needed to get over with. Yet our bad feelings had been strongly alleviated by a tremendous sense of local and global solidarity, and the crisis felt like a unique historical opportunity for desperately needed changes in global capitalism (Jandrić 2020a, 2020b; Mañero 2020). As we approach the end of the year, many of these solidarity projects continue - and have been intensified in the USA in light of the uprisings against racism and police terror-yet many people are just exhausted. Beginning with our ambiguous and precarious situation, what we need to run to now is the development of more sustainable and just ways of being. This is a global cognitive and affective project, which stretches beyond environment and indeed education. We need critique and criticism as well as courage, creativity, imagination, hope, and organization. We need new goals and new practical measures towards reaching these goals. We need new utopias, new pedagogical and political programs, designs, and experiments that fit our pandemic age of the (post-)Anthropocene.

Prior to the Covid-19 outbreak, there was no shortage of crises facing our world and way of being; crises which social movements and researchers were analysing and trying to move beyond. Indeed, revolutionary praxis has always emerged in response to and in anticipation of crises. In our age of the Anthropocene, crises have multiple planetary impacts; politics and economy cannot be thought of without the environment. Now more than ever, we need to think seriously and creatively about the postdigital pedagogies that can articulate, embody, advance, and debate new presents and futures.

According to Tyson Lewis (2010: 234), the Freirean critical utopia serves 'both a cognitive (critique of the present through imaginative reconstruction of the future) and affective (opening up the possibility for hope, for desiring differently) function'. Speaking of the cognitive function, we urgently need to develop a better understanding of living systems and their interactions with technology at all scales - from viruses, through human beings, to Earth's ecosystem. Focusing on the affective function, we need to align our hopes and desires with our (post-)Anthropogenic reality, acknowledging and negating our affectivity — our capacity to affect and to be affected by others known and unknown, human and machine, animal and mineral, subjective and objective, cognitive and affective. Crucially, this utopia is messianic as opposed to prophetic because the latter is located in the future and takes place according to chronological time, while the former is located in the now. More specifically, critical Freirean utopia 'is a creative time that exceeds chronological time by introducing future eternity as an internal surplus to the everyday' (Lewis 2010: 238). Situated between being and becoming but without disparaging the past or adhering to linear models of development or time, utopian pedagogies have an urgent and important role in intervening in our (post)-pandemic reality.

\footnotetext{
${ }^{1}$ Postdigital Science and Education 2(3) contains 56 articles about the first six months of the pandemic. See https://link.springer.com/journal/42438/volumes-and-issues/2-3. Accessed 9 November 2020.
} 
Given this, it seems useful to outline some of the lineages from which we might draw, extend, sublate, subvert, or otherwise tinker with as we think and act out new ecopedagogies, lineages that often - but not always - crosspollinate and merge. Our use of the term ecopedagogies, while unavoidably linked with the first group of literature we broach, are educational praxes that are not strictly about or for the physical environment. Instead, it names a set of pedagogies that emerge from, negotiate, debate, and produce the shifting and expansive postdigital ecologies within which we write, think, and act. We use ecopedagogies in the plural to keep the field open to various understandings and interpretations. In what follows, we will outline some themes and fields of inquiry that need to be taken into account en route to develop new postdigital ecopedagogies fit for our (post-)Anthropogenic and pandemic moment in a liberatory manner.

As a group of diverse scholars who met in 2018 to push the concept of the postdigital into the humanities and social sciences wrote: 'The postdigital is hard to define; messy; unpredictable; digital and analog; technological and non-technological; biological and informational. The postdigital is both a rupture in our existing theories and their continuation.' (Jandrić et al. 2018: 895). Thinking the postdigital as an ecosystem means that they-like all ecosystems - are not stagnant or fixed but living, breathing, expanding, and fluid. They are both conditions and questions of our nonchronological present.

\section{The Ecopedagogy Movement}

Postdigital ecopedagogies are connected to but not determined by the ecopedagogy movement that extends critical pedagogy to environmental issues. While we soon broaden some of the contours of postdigital ecopedagogies, we find it helpful to begin with this connection. Officially founded at the second Earth Summit held in Rio de Janeiro in 1992, the ecopedagogy movement's underlying ideas and principles can be traced back to the 1960s and 1970s. As it often happens, two key approaches to ecopedagogy can be illustrated using the works of critical pedagogy's key figures from that period: Ivan Illich and Paulo Freire.

In Deschooling Society, Illich starts from a deep critique of institutionalization of society. 'Medical treatment is mistaken for health care, social work for the improvement of community life, police protection for safety, military poise for national security, the rat race for productive work' (Illich 1971: 3). An institutionalized society, inevitably, has institutionalized education. "The pupil is thereby "schooled" to confuse teaching with learning, grade advancement with education, a diploma with competence, and fluency with the ability to say something new.' (Illich 1973: 3) Institutionalized education reduces human beings to producers and consumers, which makes it dehumanized. Furthermore, institutionalized society is firmly based on economic growth, which inevitably leads to ecological destruction. In response, Illich makes the radical proposal of replacing institutionalized education with non-institutional largescale educational infrastructure which strongly resembles today's Internet [for a detailed discussion of this argument, see Jandrić (2014)].

In Tools for Conviviality Illich expands this critique to human relationships with our tools. His analysis begins with a typification of six main hazards associated with 
technologies of his times: biological degradation, radical monopoly, overprogramming, polarization, obsolescence, and frustration (Illich 1973). Based on the analyses of these hazards, Illich proposed the concept of conviviality. '[O]nly within limits can machines take the place of slaves; beyond these limits they lead to a new kind of serfdom.' (Illich 1973: 12) Acknowledging these limits, Illich proposed a 'triadic relationship between persons, tools, and a new collectivity'. A society based on this triadic relationship would mean that technologies are subservient to the new political collectivity.

Illich used the concept of conviviality as 'a technical term to designate a modern society of responsibly limited tools' (Illich 1973: 12) (emphasis from the original). Convivial tools cannot be produced within capitalism - therefore, Illich develops a deeper concept of convivial reconstruction. It is worthwhile to note that the term "“convivial" is used by Illich with a special meaning', which does not correspond to typical dictionary definitions, and is associated 'with tools for joint inquiry and action' (Goodyear 2020).

Freire's work is much more focused to development needs and to the practical role of technology. Freire often used the latest technologies such as slide projectors in his projects, and during the early 1990s, he established the Central Laboratory for Educational Informatics in Sao Paolo which heavily invested in digital equipment (Kahn and Kellner 2007: 437; Freire 1993: 152). However, Freire never developed a full theory of technologies. His sporadic comments on technology in early writings such as Pedagogy of the Oppressed indicate a strong instrumentalist position': '[i]t is not the media themselves which I criticize, but the way they are used' (Freire 1972: 136). In Pedagogy of the Heart, Freire (1997: 56) sees technology as a capitalist enterprise: '[t]oday's permanent and increasingly accelerated revolution of technology, the main bastion of capitalism against socialism, alters socioeconomic reality and requires a new comprehension of the facts upon which new political action must be founded'.

To a point, Freire echoes some broader concerns explored by Illich: for example, that technologies can 'create a cult of worship' (Freire 2000: 62). Yet unlike Illich, Freire never explicitly connected digital technology with planetary ecological concerns. It is fair to say that Freire's Promethean view of technology as something that needs to be utilized for a good purpose, demystified, or even conquered is starkly opposed to Illich's Epimethean approach which seeks broad planetary balance. ${ }^{3}$

In spite of these theoretical issues, Freire's work was much more practical and applicable than Illich's utopian ideas, and it is hardly a surprise that his views were built into then-emerging fields such as critical media literacy (Kellner and Share 2007) and ecopedagogy (Kahn 2010; Misiaszek 2020; Misiaszek and Torres 2019). In Critical Pedagogy, Ecoliteracy, and Planetary Crisis: The Ecopedagogy Movement, Richard Kahn outlines the program for ecopedagogy which focuses on (1) 'ecoliteracy programs both within schools and society'; (2) creating scholar-activist coalitions to promote ecopedagogies; and (3) promoting 'critical dialogue and self-reflexive solidarity across the multitude of groups that make up the educational left' (Kahn 2010: 2728).

\footnotetext{
${ }^{2}$ For a more extensive account of Freire's views to technologies, see Kahn and Kellner (2007).

${ }^{3}$ Just before he died, Freire had been working on a new book on ecopedagogy which might have addressed these questions.
} 
Kahn's book was a key contribution to today's development of the ecopedagogy movement based on Freire's ideas. According to Misiaszek (2020: 748), '[e]copedagogy emerged from Freirean, popular education models of Latin America (Misiaszek 2011, 2018; Gadotti 2008c; Gadotti \& Torres 2009; Gutierrez \& Prado 2008; Kahn 2010), that center environmental teaching on critically understanding the connections between social and environmental violence'. Therefore, today's ecopedagogies are 'reinventions of Paulo Freire's work and the topic of an unfinished book due to his untimely death' (Misiaszek 2020: 748). This fascination with Freire's work runs so deeply, that Greg Misiaszek and Carlos Alberto Torres even wrote a missing 'fifth chapter' of Freire's Pedagogy of the Oppressed focused to ecopedagogy (Misiaszek and Torres 2019).

Already in 2010, Kahn (2010: 27) warned about 'a possible historical over-reliance upon Freirean positions within the field of critical pedagogy'. Kahn does not imply that Freire's works have lost their relevance; he simply (and rightfully) points out that we now live in a very different world. For others, critical pedagogy remains too tethered to (a particular interpretation of) Freire, too muddled and liberalized, too focused on critique, too anti-communist, and too divorced from revolutionary praxis to continue providing an adequate basis for political pedagogy (e.g. Ford 2017; Malott 2016). We use political pedagogy here to designate all forms of explicitly political educational praxis. Whether or not one chooses to endorse, develop, or leave this kind of Freirean thought, it is evident that changes within the relationship between and within the human-nature-machinic require a serious reconsideration. While we are currently strongly focused to the Covid-19 pandemic, the argument equally applies to a wide array of environmental questions (Jandrić 2020b). Today, the world's strong reliance on various digital and biotechnologies requires a deep reinvention of ecopedagogies in the light of recent socio-technological developments which embody emancipatory and oppressive tendencies.

Ecopedagogies, in fact, might be thought better as exopedagogies, which envision and enact education as a project of exodus (Ford 2019; Lewis 2012; Lewis and Kahn 2010). Exodus is neither an escape or withdrawal from our common ecologies, nor a form of opposition or negation-which can end up affirming that which they oppose. Instead, exodus is a reconfiguration of proposed alternatives, thus shifting the very terrain on which we operate. In this way, exopedagogies dwell in the endless indeterminacies of the postdigital age, the crossing and hybridization of borders between the human and nonhuman, the analog and digital, the subject and object (Ford 2020a, 2020b). As Lewis and Kahn (2010: 11) put it, "the prefix "exo" designates the beyond, an education out of bounds, whose location resides at the very limits of the recognizable-where we learn to study the zone of uninhabitability that indicates the untimely arrival of a swarm of monsters and strangers'. To put this in the postdigital era, we could turn to Dominic Pettman (2016: 3) who writes that today we are 'suspended between bot and not, between anonymous and tagged, generic and specific'. We cannot divorce ourselves from the earth, animate and inanimate beings and objects, algorithms and postdigital platforms, and the political and social restrictions and possibilities therein. Moreover, we cannot treat these as distinct entities and must instead engage them as indeterminate ecosystems that require ecopedagogies. 


\section{Critical Philosophy of Technology and Studies of Science and Technology (STS)}

During the past few decades, much of political pedagogy has either ignored emerging techno-social challenges or has approached them using one or another determinist and/ or instrumentalist position. In the meantime, philosophers such as Andrew Feenberg, Christian Fuchs, and many others have built on a body of work from Karl Marx to Frankfurt School of Social Science and developed nuanced approaches to human relationships with (today's) technology. In a recent article, Feenberg explains the relevance of this philosophy to political pedagogy:

The study of technology in philosophy and the social sciences is politically relevant today as never before. Much discussion in these fields turns on refuting cognitive errors such as the notion that nature can be 'conquered,' or that a 'great divide' isolates human beings from nature. While it is useful to refute erroneous views, a focus on beliefs tends to put the onus on the human species. Cognitive errors do not explain the power structures that are actually responsible for the civilizational crisis we are living today. (Feenberg 2020)

In the context of scientific research, critical philosophy of technology gave birth to the field of inquiry called science and technology studies or science, technology, and society studies (STS). STS explores complex relationships between culture, politics, technological innovation, and society. It claims that all knowledge and technology is socially constructed and reaches all the way into questions pertaining to collective decision-making including but not limited to democracy. A prominent theoretical and methodological approach in STS is Actor-Network Theory (ANT), which focuses to networks and relationships. Building on various posthumanist theories, ANT gives equal agency to human and nonhuman actors (Latour 2005); in more traditional disciplines such as sociology, this causes some controversy. Another theme in STS is Garrett Hardin's (1968) concept of 'tragedy of the commons' and its application to emerging commons such as the Internet. Recent developments in STS look into transformations such as commodification and assetization of various public goods (Birch and Muniesa 2020). STS research reaches all the way to the nature of human beings and often ending up in various posthumanist (Fuller 2011) and transhumanist (Fuller and Lipinska 2014) approaches.

Insights from critical philosophy of technology and science and technology studies are important for adequately understanding power structures and techno-social relationships that shape today's society, critical epistemologies, struggle against various forms of epistemicide, self-reflective solidarity, etc. In our age of the (post-)Anthropocene, these traditional concerns of political pedagogy are especially relevant for development of new postdigital ecopedagogies.

\section{Big Data, Algorithms, Artificial Intelligences, and New Capitalisms}

During our constant interactions with various digital systems, we produce huge streams of data. These large streams, often called the big data, feed algorithmic artificial intelligence (AI) systems, which 'are provided [by human programmers] with some 
initial rules of behaviour, and then they are 'taught' by large datasets. Then, a computer independently establishes various connections between input data and produces "intelligent" solutions to new problems in non-predetermined ways' (Jandrić 2019: 32). This interplay between big data and algorithms is used to sell us products, calculate our taxes and eligibility for social and other services, monitor our health, assess our students, and so on. Algorithmic processes are far from neutral, as 'the complex systems of data production and representation co-constitute the very systems they purport to describe, and in this process, they often embed, replicate or reinforce pre-existing attitudes and prejudices' (Jones 2018: 49). Furthermore, digital technologies are very carbon intensive; according to a recent report, computers now cause more carbon emissions than global aviation industry (The Shift Project 2020).

Depending on their focus, authors describe these changes using various names including data capitalism (Fuchs 2019), algorithmic capitalism (Peters and Jandrić 2018: 32), communicative capitalism (Dean 2009; Ford 2018), surveillance capitalism (Zuboff 2019), technoscientific capitalism (Birch and Muniesa 2020), high-tech and low-pay capitalism (Marcy 2009), and more. Yet a common thread concerns the changing relationship of knowledge within capitalism and the ways that knowledge - even oppositional and critical knowledge - can be captured within the circuits of surplus production (Ford 2021). Critiques of capitalism have always been at the heart of many political pedagogical projects, and engaging them as postdigital ecopedagogies can mitigate against the risk of absorption within the surplus of capital rather than the excessive surplus of utopia.

Artificial intelligence, moreover, directly pierces the heart of so much educational thought, organized as it is around knowledge and intelligence, whether it be liberal, conservative, critical, radical, and so on. In Inhuman Power, Nick Dyer-Witheford, Atle Mikkola Kjøsen, and James Steinhoff question and explore not only what artificial intelligence is but, more interestingly, what intelligence itself is. They note, for example, what they call the 'AI effect', whereby 'as soon as AI can do something, it is no longer considered to require intelligence' (2019: 9). In other words, the AI effect is a constant destabilization of what we think of what we think, and therefore of who it is that we think can think. Intelligence and knowledge, under capitalism, are defined and valued according to their ability to contribute to the production and circulation of capital, and are therefore equated with speed, efficiency, and development. Ecopedagogies have to wrestle with the implications of such definitions and their destabilizations, the extent to which we should embrace or reject the very idea that intelligence could be 'artificial' or 'organic', embodied in humans, machines, and other objects (or in the relations between and within them). We need to seriously consider the material side of digital technologies, including their carbon footprint, and, of course, decide upon further course of action with existing AI technologies and platforms.

\section{Bioinformational Capitalism and Viral Modernity}

During the second half of the twentieth century, we slowly but surely digitized every kind of traditional information source - books, music, films, and even human genome. These days, the focus of digitization has taken a turn towards the biological. In 2008, Craig Venter declared that we are in a new era defined by a shift from decades of 'digitizing biology' to 'trying to go from that digital code into a new phase of biology, 
with designing and synthesizing life', and asking if it's possible to 'regenerate life' or 'create new life, out of this digital universe' (Venter 2008). In his 2012 presentation, 'What Is Life? A 21 st Century Perspective', Venter responds to his own question: 'We can digitize life, and we generate life from the digital world. ... Scientists send digital code to each other instead of sending genes or proteins. ... It's faster and cheaper to synthesize a gene than it is to clone it, or even get it by Federal Express.' (Venter 2012)

These scientific developments are inextricably linked with political economy. We now live in the age of bio-informational capitalism 'based on a self-organizing and selfreplicating code that harnesses both the results of the information and new biology revolutions and brings them together in a powerful alliance that enhances and strengthens or reinforces each other' (Peters 2012: 105). In our pandemic times, the idea that various techno-social systems such as 'codes and ecosystems in information, publishing, education and emerging knowledge (journal) systems' (Peters and Besley 2020; Peters, Jandrić, and McLaren 2020) can be described using our insights into viral behaviour, now also attracts a lot of attention. For instance, 'the Covid-19 pandemic has sparked a viral research response' (Jandrić 2020c: 534), thus exemplifying the wider 'dialectic between biological viruses and information viruses, or more generally between inanimate matter and life' (Peters et al. 2020). Bioinformation, its emerging political economy, and viral behaviour of many social phenomena, are crucial for development of new ecopedagogies.

As Tony Sampson (2012: 4) insists, the biomedical concepts of virality are not mere metaphors for describing human behaviour. Instead, virality 'is all about the forces of relational encounter in the social field', and is 'located in an epidemiological space in which a world of things mixes with emotions, sensations, affects, and moods'. This, again, points us to our postdigital age in which the boundaries between the human and nonhuman are as porous and up for debate as ever. Digital viruses, for example, initiate a ceaseless creation, probing, breaching, and reconstruction of knowledges, subjects, and systems. The unknown becomes the organizing principle of immunology, such that 'the binary filtering of immunological self and nonself exceeds abstract diagrammatic forces" and emerges as 'part of the concrete relations established between end users and the software they encounter' (134). This, again, speaks to the cognitive and affective project of contemporary ecopedagogies, in that these flows are prior to and outside of any mind that might make sense of them, let alone capture, control, or direct them. Such ecopedagogies might acknowledge that viruses as teaching forces themselves are at times more agential than any authoritarian teaching might be.

\section{Anti-imperialist, Anti-colonial, and Decolonization Studies/Movements}

While critical pedagogy projects have generally engaged with critiques of capitalism, others have insisted on the international, global, or transnational nature of capitalism and its intrinsic relationship to colonialism and imperialism (e.g. Erevelles 2011; Ford 2017; Grande 2004; Malott 2016). Sandy Grande, for example, builds on revolutionary critical pedagogy — particularly that of McLaren — while attending to how its concepts of development and progress, which are based on linear chronology, can exclude and dismiss 'indigenous cultures as “primitive” or precapitalist entities' (Grande 2004: 88). Indeed, such a caution and critique could be waged against many strands of postdigital scholarship if they do not acknowledge the uneven development and impact of digital 
technologies, including their production, distribution, use, and impacts. In his critique of the anti-communism of critical pedagogy, Curry Malott (2016) importantly shows that anti-imperialism is also a theory and movement against colonialism and settlercolonialism and that the struggle for socialism entails - at its very core - the struggle for the self-determination of oppressed nations, including those within the USA. These struggles must not be ignored or condemned but rather looked to as inspiration for our own struggles. It is interesting to note that Freire himself too has taken this perspective, not only by calling on V. I. Lenin, Fidel Castro, and Che Geuvara in Pedagogy of the Oppressed (Freire 1972), but also in his Pedagogy in Process: Letters to GuineaBissau, where he looked to the pedagogy of Amílcar Cabral (Freire 2016).

In a globally networked postdigital age, which has transformed global structures of imperialism, settler-colonialism, and colonialism without changing their core features, issues of digital sovereignty come into play. These issues concern 'the relation between sited territories of local communities and the network systems that link us to global communications' as 'deeply shaped by geopolitical projects, corporate mechanisms, and governmental agencies' (LaBelle 2018: 82). This is why, for example, the Bolivian government under Evo Morales began constructing sovereign-that is, independent from Western political and corporate control - digital infrastructure. This also explains the recent US-led opposition to China's peaceful rise on the world stage insofar as it could provide an alternative route that would free them from the domination of Western imperialism. Today's ecopedagogies cannot be thought of without considering these recent transformations, without theorizing and experimenting adequate responses and resistances to them, without taking all forms of exploitation and all systems of oppression into account, and without grasping the cognitive and affective consequences they have on our lives and being.

\section{Postdigital Feminisms}

Feminism is a broad concept which includes a wide range of theories, social movements, and practices aimed at combatting gender-based oppression. While feminism has always questioned and challenged what gender is and the reasons why it still dominantly remains a fundamental grid through which to view the human and the social, it has increasingly taken up questions of technology and intersectionality. Some strands of feminist theory have for decades now been at the vanguard of postdigital thinking. The best example is undoubtedly Donna Haraway's 1985 article, 'A Cyborg Manifesto', originally published in Socialist Review, in which she famously declared that, 'in short, we are cyborgs', that cyborgs are 'our ontology' and the basis of 'our politics' (Haraway 2006: 118). The cyborg is not, in other words, a metaphor. By abandoning the dualisms of essence/construction, public/private, mind/body, nature/ culture, and human/technology that constrain thought and politics, the cyborg signals the postdigital ecologies through which subjects and identities are produced, oppressed, and potentially liberated.

More recently, others have considered the contemporary digitally networked ecologies of feminism. One example is what some call the 'fourth wave' of feminism. These focus on 'technological innovations such as social media', which enable feminism to consider micro and macro politics by 'situating their individual lived experiences within broader global discourses’ (Parry, Johnson, and Wagler 2019: 1). This is 
evident in 'the number of collective movements based on social, economic, and political agendas'. Probably the best example of the 'resistance and challenges to sexism, patriarchy and other forms of oppression via feminist uptake of digital communication' is the \#MeToo movement (Mendes, Ringrose, and Keller 2018: 236-237), which has significantly expanded the traditional limits of feminist activism.

None of this can escape the contradictions of bioinformational capitalism, whether they be the network effect (Dean, Medak, and Jandric 2019: 223-224), which creates a celebrity culture based on principles of viral modernity, or the way in which feminism could become just one of many possible and commodifiable identities. In its mainstream instances, the fourth wave of feminism has thus become co-constitutive with new capitalisms. On the other hand, Harriet Kimble Wrye (2009: 187) shows that fourth wave feminism also reaches beyond mere expansion of traditional feminist struggle into new media and addresses 'the limits of materialism; the need to turn from concerns about "me" to concern for the planet and all its beings; and the sense that, for us in the Fourth Wave, what is most important is to put ourselves in the service of the world'.

The fourth wave of feminism directly speaks to the bioinformational challenge of new capitalisms, viral modernity, (critical) posthumanism and transhumanism, and other postdigital and ecopedagogical challenges. By moving from dualities to networks, postdigital feminisms also name the ecologies through which postdigital ecopedagogies might intervene.

\section{Intersectionality and Identity Politics as Ecologies of Collective Resistance}

Intermixing significantly with the trajectories in the former sections, Black and antiracist scholarship has insisted on the centrality of racial categories within knowledge, research, and pedagogy, although it has predominantly centred on US and Western education. From critical race theories (see Delgado and Stefancic 2001 for an overview) to critical whiteness studies and abolitionist pedagogy, racism and white supremacy can no longer be viewed as individualist attitudes. At the same time, the proliferation (and transformation) of intersectionality theory has productively disrupted and reconfigured this scholarship. In 'Mapping the Margins', Kimberle Crenshaw (1991: 1296) presented intersectionality 'as a way of framing the various interactions of race and gender in the context of violence against women of color', while noting that it 'might be more broadly useful as a way of mediating the tension between assertions of multiple identity and the ongoing necessity of group politics'. Intersectionality is a way of understanding and thinking through the matrixes through which identities are constructed to advance the 'necessity' of political coalitions across identities - and not to further fracture political movements.

Crenshaw was building on identity politics, a concept attributed to the Combahee River Collective, a group of socialist Black feminists organizing and researching together in the 1970s. In the 'Combahee River Collective Statement', they state that their identity politics were rooted in collectivity and solidarity and an extension of Marxism (Combahee River Collective 1977). Advocating neither factionalization nor uncritical unity, identity politics as initially formulated was precisely about building alliances and solidarity - ecologies of resistance - insisting that this cannot be done without considering these complexities and contradictions (see Taylor 2017). 
The extent to which research in this trajectory has accurately or inaccurately interpreted identity politics and intersectionality is up for debate, and it runs the same risks identified in the previous section: the network effect and absorption within bioinformational capitalism. A revolutionary project of this will be fraught with tensions but will undoubtedly entail building the kinds of alliances that Crenshaw and the Combahee River Collective proposed. In addition, it will entail debating and understanding the historical origins and transformations of these structures and systems (see Alexander 2010 and Puryear 2013 for contrasting political histories and trajectories). Wherever one stands in these debates, the shape and components of ecosystems based on national and identity oppression inescapable and urgent problems for ecopedagogies to consider and address.

\section{(Critical) Posthumanism and Transhumanism}

Posthumanism is a common name for a wide array of theories which reject human dominance, and often human uniqueness, in nature. It responds to the crisis in historicity, rejects generality of human knowledge (intersecting with STS), and is strongly interested in the boundaries of our understanding of the human (see SavinBaden's [forthcoming 2021] work on postdigital humans). Transhumanism accepts many features of posthumanism yet retains human exceptionalism: 'transhumanism is an extension of the humanist project, whereas posthumanism is critical of humanism' (Bayne in Jandrić 2017: 197). Critical posthumanism focuses to the intersections between human and nonhuman agency, and 'conceptualises knowledge and capacities as being emergent from the webs of interconnections between heterogeneous entities, both human and nonhuman' (Jones 2018: 47). In ANT, this leads to radical equality between human and nonhuman actors (Latour 2005).

For Rosi Braidotti, what makes posthuman studies critical has to do with its relationship to the developments in capitalism outlined above. While her position is unclear in that at times she embraces posthumanism's alliance with cognitive capitalism while at other times she insists it keep its distance, her ultimate wager is that posthuman knowledge and thought pose too great a challenge. When the human and nonhuman become collective thinking subjects, they create 'forms and subjects of knowledge that cannot fully be captured by the schizoid speeds and acceleration of capital' (Braidotti 2019: 103).

While projects critical of humanism have a long history in educational theory and practice, over the last few decades, they have gained increasing prominence in a range of subdisciplines. It's not just the decentering of the student-teacher relationship or the inclusion of nonhuman actors as pedagogical agents that's pursued, but a complete reconceptualization and reorganization of the educational process overall. Indeed, during and after the Covid-19 lockdowns, where digital communication is at a historical peak, these new contours are crucial for the development of ecopedagogies.

\section{Critical Disability Studies}

One of the most important insurgencies in educational theory and practice has undoubtedly been the emergence of critical disability studies. Emerging with the distinction between the medical model of disability — which locates disability as a problem 
within the individual — and the social model of disability, which locates disability as the organization of society that turns an impairment into a disability, the field has since moved beyond this binary, rejecting the idea strict biology/sociology distinction. Moreover, Erevelles (2011) considers disability not as another identity but as the matrix through which identity-based oppression occurs: by placing certain groups closer to or further from 'the human'.

As we have witnessed militarized responses to the spread of the pandemic, critical disability studies push us to acknowledge the fiction of immunity in the first place. Viruses circulate in and between beings, which means that 'bodies are not closed systems - as bodies, we take in the other in all manner of ways - exchanges of breath, blood, saliva, and more' (Ferri 2018: 7). Ferri writes based on her own embodied state of autoimmunity about the ways that one's own body is not one's own body, can be pitted against itself, both defendant and victim. Autoimmunity here is not a disease to be cured but an opportunity to grasp the ecologies through which we 'are mutually dependent and often indistinguishable from one another'(14).

The war to which McGuire (2016), Ferri (2018), Sampson (2012), and others (e.g., Wagener 2020) refer is also not just a metaphor. Indeed, the ongoing history of the oppression of the disabled is one of repression, violence, and murder; one tied up in the quantifying and bioinformational logics of capitalism. For instance, Stephanie Wheeler locates the quantification of the subject in the 1800 s as a primary motor in the eugenics movement. 'During this time', Wheeler writes, 'anthropometrics became the tool that determined the need for this editing' necessary to distinguish, segregate, and eliminate non-normative ways of being (Wheeler 2017: 380). Anthropometric technologiesnow fully postdigital - continue to produce ontological hierarchies of being, orders of exclusion and (differential) inclusion that also produce surplus value for bioinformational capitalism. After all, as Nirmala Erevelles (2000) shows, the demonstration of capacity, citizenship, and so on are motivated capitalist demands for efficiency, productivity, and exchange value. As such, ecopedagogies should not be organized as development processes of acquiring knowledge but rather entail errant and wandering movements that, as the 'AI effect' does, challenge and explode our conceptions of knowledge - perhaps even queer them.

\section{Queer Theories}

While 'queer' has been taken up - reclaimed some might say —as an identity, an expansive body of literature foregrounds queerness as that which, as Lee Edelman puts it, can never be an identity but 'can only ever disturb one' (Edelman 2004: 17). While there are plenty of detractors from Edelman's general arguments, the virality of queerness continues to infect queer theory. Queerness is an unstable and opaque relation, what Sara Ahmed examines as a phenomenology. Here, queerness is not in the body but a capacity of the body as it moves throughout the world in errant yet not entirely free ways. Repetition makes bodies and spaces 'straight, which allow[s] straight bodies to extend into them, such that the vertical axis appears in line with the axis of the body' (Ahmed 2006: 92). Queer bodies disrupt such repetitions and expose the developmental lines through their deviance. Mel Chen offers an opening to such a pedagogy while discussing their own daily embodied movements, which are guided not by efficiency but instead 'follow the moment-to-moment changes in quality 
of air to inhale something that won't hurt me, turning toward a thing or away from it correspondingly' (Chen 2012: 202).

This might be an ecopedagogy of exodus that resists chronological and linear development that 'requires healthy doses of forgetting and disavowal and proceeds by way of substitutions,' which can allow us to 'access other modes of relating, belonging, and caring (Halberstam 2011: 72-73). Queering is an irreducible eruption of a glitch, which asks us to solve or dwell in it, including the queer glitches of digitally-mediated urban areas. Sara Elwood, for example, examines the queer glitches of such spaces to argue that 'apprehending a wider range of possibilities for life and liberation in "smart" cities starts from mapping theorizations such as glitch politics from Black and queer code studies to the sociospatial relations of digitally mediated urbanism' (Elwood 2020: 6). Elwood's analysis emerges within the ecosystem of postdigital urbanism, identifying and pursuing lines of closure and exposure, intelligibility and opacity, which are not prophetic but properly messianic (e.g., Muñoz 2009).

\section{Postdigital Aesthetics}

It is noteworthy that the first documented use of the term postdigital originated in aesthetic theory and in particular sound theory. In 'The aesthetics of failure: "postdigital" tendencies in contemporary computer music', Kim Cascone coins the term as a result of the fact that 'the revolutionary period of the digital information age has surely passed' (2000: 12) and digital technologies no longer significantly disrupt life. At the same time, the implications of postdigital sound at the time had not been fully fleshed out relative to the new Internet-based music scene in which digital technologies are both tools for and means of distribution of computer music. Cascone is particularly interested in the failures of digital technologies like glitches and bugs - we might add viruses - that become agential forces that act upon what was previously considered the raw material of sound.

Postdigital aesthetics take up the ways in which the postdigital era transforms the production, distribution, and reception of artistic works and practices. Do we today, as Michael Hardt and Antonio Negri put it in Empire (2000: 291), 'increasingly think like computers')? Or, because we create computers, do computers think like 'we' do? For David Golumbia, this binary is itself dangerous, as there's a lack of consideration of the wording involved: thinking - and sensing, creating, and so on-like computers is different from thinking computorily. Responding to 'The new aesthetic: Thinking like digital devices', a panel at the 2012 South by Southwest event, Golumbia (2015: 123) maintains that sight itself $i$ digital, but that digital technologies do not see like humans 'or even animals do'. They might see the same data, and information, but seeing is something embodied. Machines see qualitatively and quantitatively differently, and they see other machines in ways that the human cannot. Yet to return to Braidoitti's (2019) challenge, what remains unthought here is the subject of the sight and the separation of the machine from the human or animal, let alone the relationships between the two.

Pedagogy and educational processes more generally are always aesthetic processes in that they concern what we can sense and not sense, as well as the organization of sensibility, orders of intelligibility, or 'distribution of the sensible' of which Jacques Rancière writes (e.g., Rancière 2006). Here, the possibilities of ecopedagogies to 
embrace the aesthetic open up a variety of important pursuits with pedagogical and political consequences. Pursuing this line of aesthetics more broadly as a zone of indeterminacy and uncertainty of our age, postdigital ecopedagogies can help attune education, politics, and research to the vast and complex ecologies that act on, inform, and transform our senses and perceptions. This is true not only for other-than-human voices, but for those human voices deprived for recognition and those forms of discourse and matter that appear beyond the sensible (see Ford 2020b).

\section{(Science) Fiction and Future Studies}

Science fiction has anticipated many inventions such as submarines, space travel, and the Internet. According to Paul Levinson, 'if you look at the history of science, you will find science fiction as its profound backdrop. This relationship is two-directional, because science fiction inspires science and also has to be based on science - the interplay between science and science fiction is a trajectory of progress' (Levinson in Jandrić 2017: 286). Refining this thought, McKenzie Wark says that science fiction provides an exchange between specialized work 'trapped in worldviews and metaphors derived from that specialization'. Because science fiction is about the future and the present - or the messianic utopia - it 'is one of the things that enables you to think through relationships between different kinds of knowledge' (Wark in Jandrić 2017: 132). This argument extends beyond the narrow genre of science fiction and encompasses various other forms of fictional thinking.

A more systematic approach can be found in the area of future studies. Seminal books in the area, such as Future Shock (Toffler and Toffler 1970) and The Singularity Is Near: When Humans Transcend Biology (Kurzweil 2005), reach beyond the theoretical appeal of literature and have a wide range of applications (Bell 2003, 2004). Sohail Inayatullah (1990: 115) defines 3 perspectives 'on how the future is planned for: namely, the predictive-empirical, the cultural-interpretative, and the critical-post-structural'. In the case of Covid-19, the predictive-empirical perspective would consist of predicting future pandemics and developing appropriate responses; the culturalinterpretative perspective would consist of culturally sensitive interpretations of future pandemics and their responses; the critical-post-structural perspective would focus to pandemic power relationships and politics. In the latter perspective, '[i]nstead of the search for the objective or the grand design of things (transcendental truths that cause events and trends), the real is made political, it is historicized and made peculiar; it is no longer seen as Being itself, as an eternal verité' (lnayatullah 1990: 128).

Responding to the inherent messiness and non-predictability of our postdigital existence, (science) fiction and future studies offer inspiration and years of methodological experience in grappling with the future. In our current pandemic moment, which require urgent development of new (approaches to) present and future, this inspiration and experience is crucial for the development of new ecopedagogies.

\section{Myth, Religion, and Belief}

Humans are not just beings of logic - we are also beings of myth and faith (McLaren 2020: 255). Critical pedagogy has recognized this a long time ago, especially (but far from exclusively) through strong connections with the Latin American tradition of 
liberation pedagogy. According to Peter McLaren, ' $[\mathrm{t}]$ he realm of religion is the realm of myth, symbol, art, mystery, legend, theater, and poetry - realms where we can delve deeply into the meaning of life' (in McLaren 2020: 143). As '[w]e need to understand the world in order to change it', claims McLaren, 'liberation theology needs social science as much as social science needs theology' (in McLaren 2020: 99). Setting aside the debates on religion within Marxism, liberation theology has clearly made positive contributions to the anti-imperialist, anti-colonial, and de-colonial movements outlined above. Various forms of spirituality are influential in our postdigital reality in both reactionary and liberatory forms.

One does not need to belong to an organized religion to succumb to placing our own customs and beliefs before (sometimes very evident) truth. A typical case in point is the question of post-truth and fake news, which stems from our postdigital 'environment which can seduce people into having or maintaining false beliefs with such swift stealth that the power to deceive goes unchecked' (McKenzie, Rose, and Bhatt 2020). It is a long way from genuine belief in God to being deceived into believing that a deepfake viral video is real and/or believing into a developed conspiracy theory. However, these three types of belief, and numerous shades of grey in between, are closely linked to virtue epistemology, which is a branch of philosophy that is concerned with the intellectual and character qualities a person requires in order to inquire about the state of knowledge' (MacKenzie and Bhatt 2020: 1). Looking at history and philosophy of science, Steve Fuller reaches all the way to the very basics of Western civilization and argues that 'we wouldn't have gone down the path of modern scientific inquiry at all without the predominance of the world-view associated with the Abrahamic faiths' (Fuller and Jandrić 2019: 203).

From inquiring into deep philosophical questions about one's own purposes and methods, to reaching out to religious believers, to addressing obvious threats arriving from climate change deniers, anti-vaccinationists, and believers in other conspiracy theories, today's ecopedagogies cannot will away the ongoing centrality of myth, religion, and belief in our postdigital ecologies.

\section{Towards New Postdigital Ecopedagogies}

These days, Freire's messianic utopia with its hopeful and courageous view of the future and to the futurity that is here now as a surplus is more needed than ever. Political pedagogies offer decades of experience in the trenches of formal and informal education, finding ways through the direst of crises, reinventing themselves across contexts, and even contributing to revolutionary movements. While the ecopedagogy movement is undoubtedly relevant to our pandemic moment, it is still too deeply connected to the Freirean understanding of human relationships with technology and is therefore ripe for a deep reinvention and reconsideration in and for our postdigital, bioinformational reality. Postdigital ecopedagogies need not approach the Freire or Illich as the Fathers from which they cannot depart. In fact, it may be that the postdigital era - in which our notions of intelligence and knowledge, subjectivity and machinery, sovereignty and dependency are being contested, reified, and reconfigured constantly-ecopedagogies can benefit just as much from a rupture with that legacy. 
The contestations, lineages, debates, and directions charted in this article address some of the contemporary coordinates of our postdigital ecologies. Some of these perspectives are not fully commensurable, while others significantly overlap and use different paths to arrive to similar conclusions. We are at the very brink of the postdigital age; at this stage, this messy and sometimes paradoxical nature of our knowledge is just a part of the game. If communicative and bioinformational capitalisms continue, then one day, probably, our postdigital condition will be condensed in concise encyclopaedia entries and routinely explained by undergraduates. One task is to ensure this does not happen, and that the postdigital remains-for as a long as it is productive - a concept that constantly resists any final definition.

At this moment in history, however, we cannot be sure which of the listed (and indeed non-listed) perspectives and/or combinations thereof will be more relevant than the next one. This will depend on the cognitive and affective dimensions of our utopic pedagogic imaginings. Yet we do know, and without hesitation, that the questions and dilemmas of our postdigital age need to be addressed in educational theory, policy, politics, and practice, and that ecopedagogies are a particularly ripe place for their growth. We may not know where we are going, and we may have even less idea about how we might get there, yet we cannot remain idle as the new ecologies of capitalism and imperialism, with their ontological hierarchies and divisions, tailor our destiny.

Ecopedagogies have to, then, consider the nexuses identified above (and more!), while disavowing fantasies of political, bodily, and digital immunity and embracing the opacity, contingency, uncertainty, and interdependent vulnerability of all things to transform the animacy hierarchy into a horizontal configuration of human/nonhuman/ object. We need to invent new postdigital ecopedagogies that are critical and creative, certain and indeterminate, transparent and opaque, and that accept and negotiate the contamination of the constantly shifting borders between humans, machines, nature, nonhuman animals, and objects. In our pandemic moment, the lines of inquiry identified in this article — while far from exhaustive — offer some signposts and references we might use to develop such ecopedagogies. But we ourselves remain open to, curious about, and excited for the ecopedagogies that can emerge from the excessive future that is here already.

Acknowledgements We extend our thanks to Sarah Hayes, Tim Fawns, and Mark Carrigan, for their valuable comments and suggestions on earlier versions of this article.

\section{References}

Ahmed, S. (2006). Queer phenomenology: orientations, objects, others. Durham: Duke University Press.

Alexander, M. (2010). The new Jim Crow: mass incarceration in the age of colorblindness. New York: The New Press.

Bell, W. (2003). Foundations of futures studies I: history, purposes, knowledge. New Brunswick, NJ: Transaction Publishers.

Bell, W. (2004). Foundations of futures studies II: values, objectivity and the good society. New Brunswick, NJ: Transaction Publishers.

Birch, K., \& Muniesa, F. (Eds.). (2020). Assetization: turning things into assets in technoscientific capitalism. Cambridge, MA: MIT Press.

Braidotti, R. (2019). Posthuman knowledge. Cambridge: Polity Press. 
Cascone, K. (2000). The aesthetics of failure: 'post-digital' tendencies in contemporary computer music. Computer Music Journal, 24(4), 12-18.

Chen, M. Y. (2012). Animacies: biopolitcs, racial mattering, and queer affect. Durham: Duke University Press.

Combahee River Collective. (1977). The Combahee River Collective statement. https:/www.blackpast.org/ african-american-history/combahee-river-collective-statement-1977/. Accessed 12 November 2020.

Crenshaw, K. (1991). Mapping the margins: Intersectionality, identity politics, and violence against women of color. Stanford Law Review, 43(6), 1241-1299. https://doi.org/10.2307/1229039.

Dean, J. (2009). Democracy and other neoliberal fantasies: communicative capitalism and left politics. Durham and London: Duke University Press.

Dean, J., Medak, T., \& Jandrić, P. (2019). Embrace the antagonism, build the party! The new communist horizon in and against communicative capitalism. Postdigital Science and Education, 1(1), 218-235. https://doi.org/10.1007/s42438-018-0006-7.

Delgado, R., \& Stefancic, J. (2001). Critical race theory: an introduction. New York and London: New York University Press.

Dyer-Witheford, N., Kjøsen, A. M., \& Steinhoff, J. (2019). Inhuman power: artificial intelligence and the future of capitalism. London: Pluto Press.

Edelman, L. (2004). No future: queer theory and the death drive. Durham: Duke University Press.

Elwood, S. (2020). Digital geographies, feminist relationality, Black and queer code studies: thriving otherwise. Progress in Human Geography. https://doi.org/10.1177/0309132519899733.

Erevelles, N. (2000). Educating unruly bodies: critical pedagogy, disability studies, and the politics of schooling. Educational Theory, 50(1), 25-47. https://doi.org/10.1111/j.1741-5446.2000.00025.x

Erevelles, N. (2011). Difference and disability in global contexts: enabling a transformative body politic. New York: Palgrave Macmillan.

Feenberg, A. (2020). Critical constructivism: an exposition and defense. Logos: a journal of modern society \& culture, Fall. http://logosjournal.com/2020/critical-constructivism-an-exposition-and-defense/. Accessed 6 November 2020.

Ferri, B. (2018). Metaphors of contagion and the autoimmune body. Feminist Formations, 30(1), 1-20. https://doi.org/10.1353/ff.2018.0001.

Ford, D. R. (2017). Education and the production of space: Political pedagogy, geography, and urban revolution. New York: Routledge.

Ford, D. R. (2018). Queer communist study: the sinthomostudier against the capital-debt-learning regime. Journal of Curriculum and Pedagogy, 15(1), 8-23. https://doi.org/10.1080/15505170.2018.1437575.

Ford, D. R. (2019). Pedagogy of the "not:" negation, exodus, and postdigital temporal regimes. Postdigital Science and Education, 1(1), 104-118. https://oi.org/10.1007/s42438-018-0009-4.

Ford, D. R. (2020a). The aesthetics of exodus: Virno and Lyotard on art, timbre, and the general intellect. Cultural Politics, 16(2), 253-269. https://doi.org/10.1215/17432197-8233434.

Ford, D. R. (2020b). The sonic aesthetes of writing: Pedagogy, timbre, and thought. Pedagogy, Culture and Society, 1-14. https://doi.org/10.1080/14681366.2020.1829012.

Ford, D. R. (2021). Inhuman educations: Jean- François Lyotard, pedagogy, thought. Boston: Brill.

Freire, P. (1972). Pedagogy of the oppressed. New York: Herder \& Herder.

Freire, P. (1993). Pedagogy of the city. New York: Continuum.

Freire, P. (1997). Pedagogy of the heart. New York: Continuum.

Freire, P. (2000). Cultural action for freedom. Cambridge, MA: Harvard Educational Review.

Freire, P. (2016). Pedagogy in process: letters to Guinea-Bissau. London: Bloomsbury.

Fuchs, C. (2019). Karl Marx in the age of big data capitalism. In D. Chandler \& C. Fuchs (Eds.), Digital Objects, Digital Subjects: Interdisciplinary Perspectives on Capitalism, Labour and Politics in the Age of Big Data (pp. 53-71). London: University of Westminster Press. https://doi.org/10.16997/book29.d.

Fuller, S. (2011). Humanity 2.0: what it means to be human past, present and future. London: Palgrave Macmillan.

Fuller, S., \& Jandrić, P. (2019). The postdigital human: making the history of the future. Postdigital Science and Education, 1(1), 190-217. https://doi.org/10.1007/s42438-018-0003-x.

Fuller, S., \& Lipinska, V. (2014). The proactionary imperative: a foundation for transhumanism. London: Palgrave Macmillan.

Golumbia, D. (2015). Judging like a machine. In D. M. Berry \& M. Dieter (Eds.), Postdigital aesthetics: art, computation, and design (pp. 123-135). New York: Palgrave Macmillan.

Grande, S. (2004). Red pedagogy: native American social and political thought. Lanham: Rowman \& Littlefield.

Halberstam, J. (2011). The Queer Art of Failure. Durham and London: Duke University Press. 
Haraway, D. (2006). A cyborg manifesto: science, technology, and socialist-feminism in the late $20^{\text {th }}$ century. In J. Weiss, J. Nolan, J. Hunsinger, \& P. Trifonas (Eds.), International handbook of virtual learning environments (pp. 117-158). New York: Springer.

Hardin, G. (1968). The tragedy of the commons. Science, 162(3859), 1243-1248. https://doi.org/10.1126/ science.162.3859.1243.

Hardt, M., \& Negri, A. (2000). Empire. Cambridge, MA: Harvard University Press.

Illich, I. (1971). Deschooling society. London: Marion Boyars.

Illich, I. (1973). Tools for conviviality. London: Marion Boyars.

Inayatullah, S. (1990). Deconstructing and reconstructing the future: predictive, cultural and critical epistemologies. Futures, 22(2), 115-141. https://doi.org/10.1016/0016-3287(90)90077-U.

Jandrić, P. (2014). Deschooling virtuality. Open Review of Educational Research, 1(1), 84-98. https://doi.org/ 10.1080/23265507.2014.965193.

Jandrić, P. (2017). Learning in the age of digital reason. Rotterdam: Sense.

Jandrić, P. (2019). The postdigital challenge of critical media literacy. The International Journal of Critical Media Literacy, 1(1), 26-37. https://doi.org/10.1163/25900110-00101002.

Jandrić, P. (2020a). Postdigital research in the time of Covid-19. Postdigital Science and Education, 2(2), 233-238. https://doi.org/10.1007/s42438-020-00113-8.

Jandrić, P. (2020b). The postdigital challenge of pandemic education. Journal of Contemporary Educational Studies, 71(4).

Jandrić, P. (2020c). The day after Covid-19. Postdigital Science and Education, 2(3), 531-537. https://doi.org/ 10.1007/s42438-020-00195-4.

Jandrić, P., Jaldemark, J., Hurley, Z., Bartram, B., Matthews, A., Jopling, M., Mañero, J., MacKenzie, A., Irwin, J., Rothmüller, N., Green, B., Ralston, S. J., Pyyhtinen, O., Hayes, S., Wright, J., Peters, M. A., \& Tesar, M. (2020). Philosophy of education in a new key: who remembers Greta Thunberg? Education and environment after the coronavirus. Educational Philosophy and Theory, 1-21. https://doi.org/10.1080/ 00131857.2020.1811678.

Jandrić, P., Knox, J., Besley, T., Ryberg, T., Suoranta, J., \& Hayes, S. (2018). Postdigital science and education. Educational Philosophy and Theory, 50(10), 893-899. https://doi.org/10.1080/00131857. 2018.1454000 .

Jones, C. (2018). Experience and networked learning. In N. B. Dohn, S. Cranmer, J. A. Sime, M. de Laat, \& T. Ryberg (Eds.), Networked learning: reflections and challenges (pp. 39-55). Cham: Springer. https://doi. org/10.1007/978-3-319-74857-3_3.

Kahn, R. (2010). Critical pedagogy, ecoliteracy, \& planetary crisis: the ecopedagogy movement. New York: Peter Lang.

Kahn, R., \& Kellner, D. (2007). Paulo Freire and Ivan Illich: technology, politics and the reconstruction of education. Policy Futures in Education, 5(4), 431-448. https://doi.org/10.2304/pfie.2007.5.4.431.

Kellner, D., \& Share, J. (2007). Critical media literacy is not an option. Learning Inquiry, 1(1), 59-69. https:// doi.org/10.1007/s11519-007-0004-2.

Kurzweil, R. (2005). The singularity is near: when humans transcend biology. New York: Viking.

LaBelle, B. (2018). Sonic agency: sound and emergent forms of resistance. London: Goldsmith Press.

Latour, B. (2005). Reassembling the social: an introduction to actor-network-theory. Oxford: Oxford University Press.

Lewis, T. E. (2010). Messianic pedagogy. Educational Theory, 60(2), 231-248. https://doi.org/10.1111/j. 1741-5446.2010.00355.x.

Lewis, T. E. (2012). Exopedagogy: on pirates, shorelines, and the educational commonwealth. Educational Philosophy and Theory, 44(8), 845-861. https://doi.org/10.1111/j.1469-5812.2011.00759.x.

Lewis, T. E., \& Kahn, R. (2010). Education out of bounds: reimagining cultural studies for a posthuman age. New York: Palgrave Macmillan.

MacKenzie, A., \& Bhatt, I. (2020). Lies, bullshit and fake news. Postdigital Science and Education, 2(1), 1-8. https://oi.org/10.1007/s42438-019-00085-4.

MacKenzie, A., Rose, J., \& Bhatt, I. (2020). Dupery by Design: The epistemology of deceit in a postdigital era. Postdigital Science and Education. https://doi.org/10.1007/s42438-020-00114-7.

Malott, C. S. (2016). History and education: engaging the global class war. New York: Peter Lang.

Mañero, J. (2020). Postdigital brave New World and its educational implications. Postdigital Science and Education, 2(3), 670-674. https://doi.org/10.1007/s42438-020-00129-0.

Marcy, S. (2009). High tech, low pay: a Marxist analysis of the changing character of the working class. New York: World View Forum.

McGuire, A. (2016). War on autism: on the cultural logic of normative violence. Ann Arbor: University of Michigan Press. 
McLaren, P. (2020). Networked religion: metaphysical redemption or eternal regret? Postdigital Science and Education. https://doi.org/10.1007/s42438-020-00112-9.

Mendes, K., Ringrose, J., \& Keller, J. (2018). \#MeToo and the promise and pitfalls of challenging rape culture through digital feminist activism. European Journal of Women's Studies, 25(2), 236-246. https://doi.org/ $10.1177 / 1350506818765318$.

Misiaszek, G. W. (2020). Countering post-truths through ecopedagogical literacies: teaching to critically read 'development' and 'sustainable development'. Educational Philosophy and Theory, 52(7), 747-758. https://doi.org/10.1080/00131857.2019.1680362.

Misiaszek, G. W., \& Torres, C. A. (2019). Ecopedagogy: the missing chapter of pedagogy of the oppressed. In C. A. Torres (Ed.), The Wiley handbook of Paulo Freire (pp. 463-488). Hoboken, NY: Wiley-Blackwell. https://doi.org/10.1002/9781119236788.ch25.

Muñoz, J.-E. (2009). Cruising utopia: the then and now of queer futurity. Durham: Duke University Press.

Peters, M., Jandrić, P., \& McLaren, P. (2020). Viral modernity? Epidemics, infodemics, and the 'bioinformational' paradigm. Educational Philosophy and Theory, 1-23. https://doi.org/10.1080/ 00131857.2020 .1744226 .

Peters, M. A. (2012). Bio-informational capitalism. Thesis Eleven, 110(1), 98-111. https://doi.org/10.1177/ 0725513612444562.

Peters, M. A., \& Besley, T. (2020). Pandemic education and viral politics. London: Routledge.

Peters, M. A., \& Jandrić, P. (2018). The digital university: a dialogue and manifesto. New York: Peter Lang. Pettman, D. (2016). Infinite distraction: paying attention to social media. Cambridge: Polity Press.

Puryear, E. (2013). Shackled and chained: mass incarceration in capitalist America. San Francisco: Liberation Media.

Rancière, J. (2006). The politics of aesthetics, trans. Bloomsbury: G. Rockhill. London.

Sampson, T. D. (2012). Virality: contagion theory in the age of networks. In Minneapolis. MN: University of Minnesota Press.

Savin-Baden, M. (Ed.). (2021). Postdigital Humans: Transitions, Transformations and Transcendence. Singapore: Springer.

Taylor, K.-Y. (Ed.). (2017). How we get free: Black feminism and the Combahee River Collective. Chicago, IL: Haymarket.

The Shift Project (2020). Lean ICT towards digital sobriety. Paris: The Shift Project. https://theshiftproject.org/ wp-content/uploads/2019/03/Lean-ICT-Report The-Shift-Project 2019.pdf. Accessed 18 November 2020 .

Toffler, A., \& Toffler, A. (1970). Future shock. New York: Bantam.

Venter, C. (2008). On the verge of creating synthetic life. TED 2008. https://www.ted.com/talks/craig_venter_ is_on_the_verge_of_creating_synthetic_life. Accessed 7 October 2020.

Venter, J. C. (2012). What is life? A 21st century perspective. On the 70th anniversary of Schroedinger's lecture at trinity college. The Edge. https://www.edge.org/conversation/j_craig_venter-what-is-life-a-21stcentury-perspective. Accessed 20 November 2020 .

Wagener, A. (2020). Crushed by the wheels of industry: war, heroes, and domestic recolonization in the time of Covid-19. Postdigital Science and Education, 2(3), 576-580. https://doi.org/10.1007/s42438-02000140-5.

Wheeler, S. K. (2017). The construction of access: the eugenic precedent of the Americans with disability act. Continuum: Journal of Media \& Cultural Studies, 31(3), 377-387. https://doi.org/10.1080/10304312. 2016.1275132 .

Wrye, H. K. (2009). The fourth wave of feminism: psychoanalytic perspectives introductory remarks. Studies in Gender and Sexuality, 10(4), 185-189. https://doi.org/10.1080/15240650903227999.

Zuboff, S. (2019). The age of surveillance capitalism: the fight for a human future at the new frontier of power. New York: PublicAffairs.

Goodyear, P. (2020). Convivial technologies and networked learning. 30 September. https://petergoodyear. net/2020/09/30/convivial-technologies-and-networked-learning/. Accessed 6 December 2020.

Parry, D. C., Johnson, C. W., \& Wagler, F-A. (2019). Fourth wave feminism: Theoretical underpinnings and future directions for leisure research. In D. C. Parry (Ed.), Feminisms in Leisure Studies: Advancing a Fourth Wave (pp. 1-12). Oxon and New York: Routledge. 